\title{
太陽エネルギーとエコロジー
}

\section{I ・まえがき}

“人類は生物の一員であるということから，すべての 発想がなされなければならない、などというような言葉 をよく耳にする．乙の生物とはいったい何んであろうか と成書を調へててるが，“生物、の定義は大変難しいら しく, 適当な表現が見当らない，ただ“太陽エネルギー を得ててれを次に伀達する太陽エネルギー連鎖の中にあ る、ととは共通した特徴のように思われる。

緑色植物は太陽加らの光量子を吸収し $\mathrm{CO}_{2}$ と水之を 結びつけ炭水化物として光エネルギーをたくわえ, 自分 自身の生活に必要な物質を合成する。乙れをわれわれは 光合成之呼んでいるが，合成されたものの一部分は呼吸 によって再びエネルギーの放出を行ない “生きる、源泉 とし, 他のある部分は脂肪に変化したり, 土壤から吸収 する無機元素之結合して蛋白質, 其の他の有機物質を合 成したりしてまてとに見事な有機物生産工場を組立てて いる. これに対して植物以外の生物はすべて食物という 名で植物の固定した太陽エネルギーを得て生命を支えて きている.人類はもち万ん土壤中の目に見えない微生物 むすべて有機物を分解しエネルギーを放出して生きてい るわけである. 肉食動物あ肉の源をたずねると植物が固 定した太陽エネルギーとなり,すべて太陽エネルギーに 連らなって生きている. したがって植物以外の生物は植 物にぶら下ってエネルギーを得ている寄生生物である. しかしての寄生生物む, 呼吸によって有機物をもとの $\mathrm{CO}_{2}$ と水之に分解して植物にかえし植物が生きるための 材料づくりに寄与している. こうして生物はエネルギー と物質との見事な循環系をつくり栄えている.

光合成による有機物質の年産額は $10^{10}$ から $10^{11}$ トンに 達するあのと推定され, 高度に工業化された現代におい ても, 人類の生活は基本的には依然として生物生産に依 存しておる. 化石燃料之呼ばれる石炭・石油はいうまで

* 大阪府立大学農学部教授
矢 吹 万 寿*

あなく植物が固定した太陽エネルギーに外ならない．人 類はいま食糧とエネルギーの問題に直面しておりてれを 解决することなしに将来の人類の存在はあり得ないが， てれらの鍵はすべて植物にかかっているようにあ思われ る.

\section{II. 植物に対する光の作用}

植物は光とともに生きつづけなければならないから， その土地の光条件を十分利用するような性質を長い年代 の中に獲得している．その中でさきに述べた植物みずか ら太陽エネルギーを固定する光合成はまことに大規模で すばらしい現象であるが，それ以外にも光の方向に向く 性質 (屈光反応), 昼の長さ, 夜の長さを測り，季節を 知り，四季抢りおりに花を咲かせ実を結ばせる性質（形 態形反応), あるいは形態反応をおさえる性質など光関 係した多くの性質を持っている．てういう反応はどのよ うな光でもよいかというとそれぞれ受け持ちがある.こ れを第 1 図に示した. われわれはこれを作用スペクトル 乙呼んでいるが，反応の波長範囲はほぼ可視光の領域内 で行なわれている. 可視光の範囲内之言ってあ主に赤色 と青色の領域に集中し, 緑の部分の吸仪は少ない，植物 が緑色をしているのはこの波長領域を反射, 透過して吸 収量が少ないととを示すあのである.太陽光のエネルギ 一分布は乙の領域がもっとも多いが，ぞうしてての領域 の光を利用しないのか，大きい疑問で植物発生時代に受 けていた光のスペクトルとか, その後の生活の場の変化 などから論議されているが，まだ解き明されていない。 人間の視感度曲線も描いたが, 植物の作用スペクトルと はだいぶ異なっている.人間の発生は植物より暑く,現在 地上にやってくる太陽光を有効に利用するようになって いるように思われる. また図中ハッチングした領域は植 物の光反応感度が最小な波長域であり, 街路や高速道路 の照明にはこの波長の光を使用すると植物に対する影響 は少ないあのと考えられ, Safty light と呼ばれている. この部分は人間の視感度があっとあ高いとてろであり， 


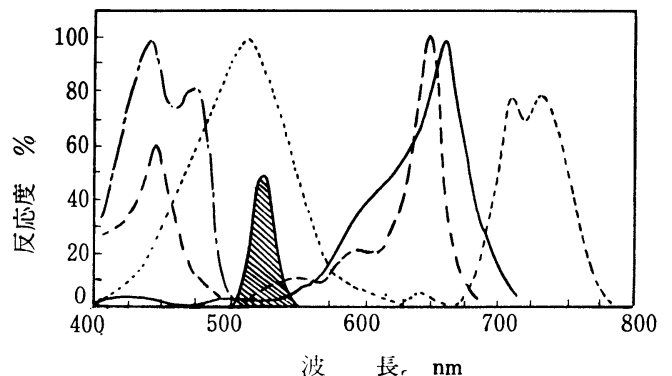

- - - 届光性

- - - クロロフイル合成

- 光形態反応 (赤色の効果)

-...- 区赤色効果

…….... 視感度

斜線部分は Safe light こ呼ばれ，植物の光反忘 感度が最小な領域

第1図 植物の光区応度 (Withron)

しかし演色性はよくないが道路照明としては好ましいあ のと考える.

これらの反応にどの位のエネルギーが必要とするかに ついて後に述べるが，屈光反応とか形態形成反応はきわ めて僅かでおてり，月の光であ感ずるといわれる程であ る. これに対し光合成反応には多くのエネルギーを必要 とするが，太陽からの入射エネルギーと比べるとそれは 約 $2 \sim 3 \%$ 程度を利用するに過ぎない. より多く固定し てくれたほうがよいように思われるが，それは身勝手ら しい. あまり多く固定されると地球上が冷却することに なる.太陽エネルギーが $1 \%$ 少くなると地球上の気温は 1.3〜 $1.5^{\circ} \mathrm{C}$ 低下するという (Budyko). 自然はよくした あのである.

\section{III. 光合成と太陽エネルギー}

光合成反応のもっとも単純な 方程式は次式で示され る.

$$
\mathrm{CO}_{2}+\mathrm{H}_{2} \mathrm{O}+\stackrel{\downarrow h \nu}{112 \mathrm{Kcal}} \rightleftarrows \mathrm{CH}_{2} \mathrm{O}+\mathrm{O}_{2}
$$

しかし光合成反応で発生する $\mathrm{O}_{2}$ は水の分解によるもの でこの式では不備のため次式で表わしている.

$$
\mathrm{CO}_{2}+2 \mathrm{H}_{2} \mathrm{O}+112 \mathrm{Kcal} \underset{\text { 呼 吸 }}{\stackrel{\text { 光合成 }}{\rightleftarrows}} \mathrm{CH}_{2} \mathrm{O}+\mathrm{O}_{2}+\mathrm{H}_{2} \mathrm{O}
$$

炭水化物 $30 \mathrm{gr}$ (1 mol) に対し $112 \mathrm{Kcal}$ のエネルギーを 必要とするととになる. アインシュタインの量子仮説に よると光量子の持つエネルギー（E）は

$$
\mathrm{E}=\mathrm{h} \frac{\mathrm{c}}{\lambda}=\mathrm{h} \nu
$$

で示される. ここに $\mathrm{h}$ : プランクの常数, $\nu$ : 周波数, $\mathrm{c}$ : 光の速度, $\lambda:$ 光の波長である.
したがって赤の光量子の持つエネルギーは $43.6 \mathrm{Kcal}$ (660 mm), 青色は $65.5 \mathrm{Kcal}(436 \mathrm{~nm})$ となる. $\mathrm{CO}_{2} 1$ 個の分子の同化に 8 ～12個の光量子を必要とするという 結果が多いが，10個とするとその効率は赤色で $26 \%$ ，青 色で $17 \%$ となる。

これらの事柄は単に化学変化でのエネルギーのやり取 りに過ぎず，実際に光が植物にあたって生活している時 の光（熱）の収支はまことに複雑で, しかも“光合成は 放射線物理学のかなたに始まり, 生態学のはるかかな たに終る、あのであり，“時間過程で表現すれば，量子 吸収から変換過程は $10^{-15} \sim 10^{-9}$ 秒の時期であり, 生理 学は $10^{-1} \sim 10^{4}$ 秒, 生態学は $10^{2}$ 秒以上の現象であり、 (KEMEN) 実際の光合成量と光合成の機作との問には ほとんど無関係に近い。

\section{a.太陽放射と葉による光の吸収}

太陽は約 $6,000^{\circ} \mathrm{K}$ の温度の放射体に相当する放射を行 っているが, 実際地表に到達する光のエネルギー分布を 示すと第 2 図のごとくであって，理論から計算されるむ

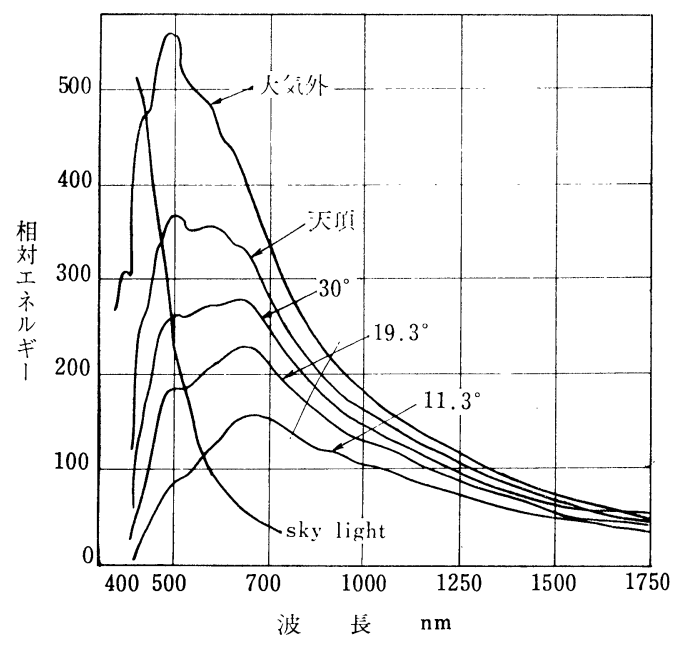

第 2 図 太陽光のスペクトル 太陽高度によってスペクトルは異なり， 高エネルギー部が低高度ほど長波長側 に移行する

のと可なり異っている. 大気は透明でないから太陽光を 吸収するため，光が大気を通過する厚さによってスペク トル分布は異ってきて, 太陽高度が低くなり通過する大 気の厚さが厚くなると短波長域の吸収が多く, $650 \mathrm{~mm}$ 以上の波長域に最大值がくる. 夕陽が赤いことからもう なづけることである.このととは植物にとって大変重要 なととと考えられる. 日長反応（形態形成反成）に関係 する波長域は第 1 図からもわかるごとく，650～735mm の赤色光にあり, 赤い光によって夜が来たり朝が来たり 
するととを知るわけである。

太陽高度によってスペクトルがちがうことは緯度によ っても異ることを意味するととであある. これは生態学 的にあ大变興味深いととである. この点は後に述べた い.

地表で太陽エネルギーを測定すると平均的に可視部が 全体の $45 \%$ ，紫外部が $5 \%$ ，赤外部が約 $50 \%$ というのが 大体の目安となっている. 大阪などのごとく大気が極端 に污染されている地带では紫外部の短い処はほとんど地 表には到達せず, 生理的に問題となる点である.

植物が光を利用するためにはまず光を吸収しなけれぱ ならない。第 3 図に葉の平均的な区射, 吸収, 透過率を

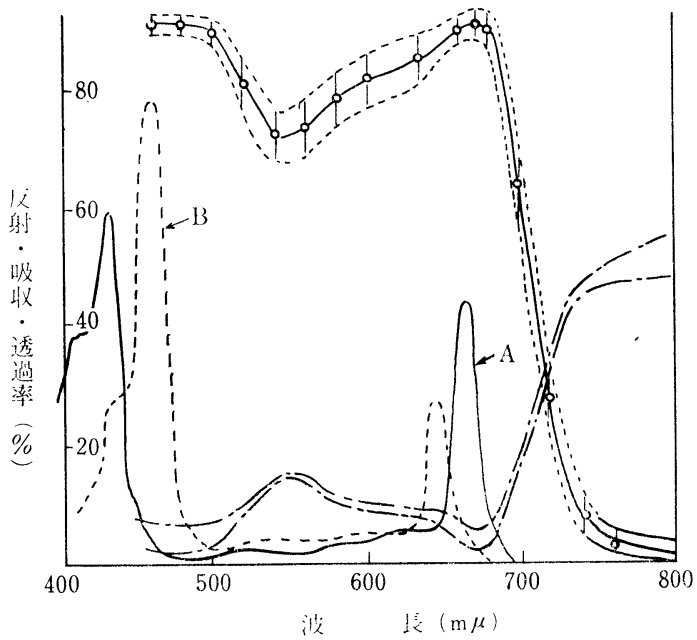

第3 図葉における放射の反射 $(\mathrm{R})$, 吸収 $(\mathrm{A})$, 透 過 (T) 一可視部 (Kleshnin \& Shul'gin 1959）約80種の植物についての測定值の平 均, $\mathrm{A}$ の点線は種間変異の幅） $\mathrm{A}, \mathrm{B}$ はク ロロフィル $\mathrm{a}$ および $\mathrm{b}$ の吸収スペクトル
と葉による透過光が多くなり，緑色の領域が多くなり， 下葉によっては重要な意味を持ってくるようになる。

\section{b. 日本の日射分布}

適当な分布図が手元に見当らないが，大略は第 9 図に 揭げた日本の光合成能分布図から推測することができ る. 大気上部への日射量は幾何学的に緯度によって决っ てくるが，地表へは雲量が支配的となってくる，ての分 布からとくに指摘したいことは大阪・東京などの工業地 帯で日射量の少ないととである・とれは言うまであなく 工場からのダストあるいはスモッグによるあのであり， 最近はさらにての傾向が顕著になっているものと考えら れる．英国であ同様な報告があり，ロンドンの日射量は 郊外のキコウの $80 \%$ 以下となっており, 他の工業地帯で あ日照時間に対する日射量が非污染地帯よりあ少くなっ ている.とれはスペクトルの変化とともに重要であり, 詢に瞉慮すべき事態である.

\section{c. 世界の日射量の分布}

Budyko が緯度と雲量とから計算したものを第 4 図に 示す. 今日砂漠となっているサ八ラ，アラビアおよびオ 一ストウリアなどがもっとも多く, 東南アジアとくにマ レーシア，インドネシアが少ない，日本も緯度から考え て少く, シベリアが想像以上に多い. シベリアの多いの は夏期日長時間が長いととからくるものである．との日 射分布四から今後地球上の農業開発について多くの示唆 を与えるものがある・

\section{d. 植物の光合成効率}

$\mathrm{i}$; 単葉の光合成量 一枚の葉の光強度と光合成量と の関係は第 5 図に幾つかの植物のむのを示した. 光の量 を増していくと光合成量は増加していくが，光が強くな ると次第に増加の割合が小さくなり，ある光量以上にな ると光合成量は增加しなくなり，一定值となってくる.

示した.またクロロフィルの吸 収スペクトルも示した. クロロ フィルは顕著なスペクトル分布 を示しているが，葉には各種の 色素があり，80～90\%の光を吸 収し，緑色の領域であ65～70\% の吸収がある. 吸収された光の ほとんどが熱となり，苯温を高 わ, 空気中に奪的れたり, 葉面 からの蒸散のための気化热に変 化し，さきにも触れたでとく光 合成に使われるエネルギーは入 射光の $1 \sim 2 \%$ に過ぎない.

植物群落の生育層内部になる

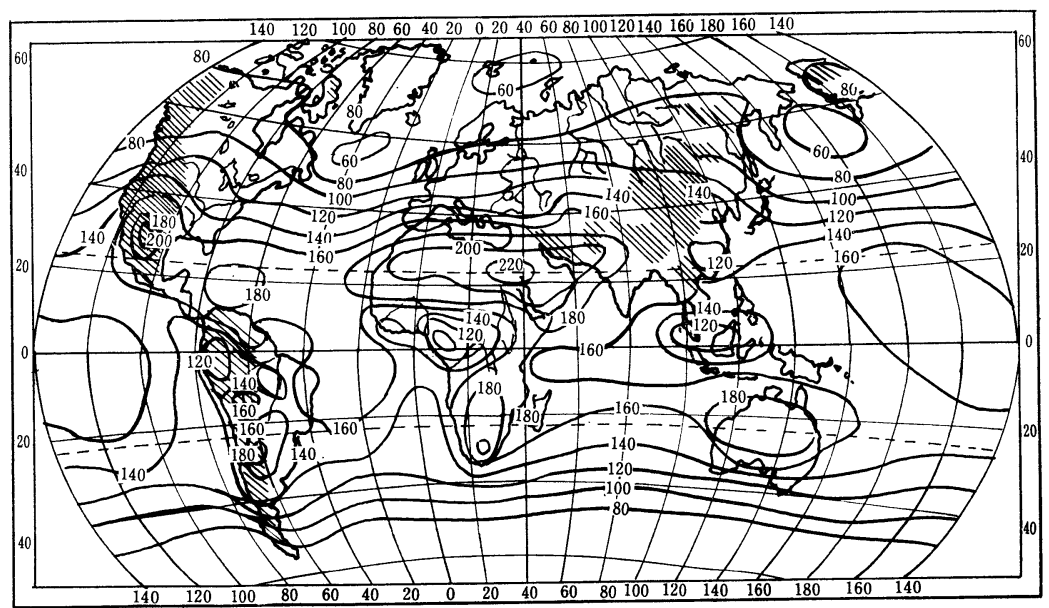

第 4 図 日射の年間量 $\left(\mathrm{kcal} / \mathrm{cm}^{2} \mathrm{year}\right)$ 


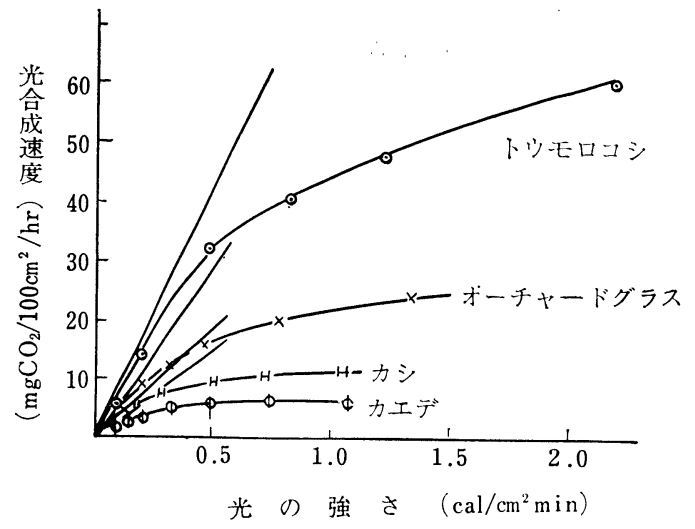

第 5 図 自然光下の 4 種の植物の光合成亡光の 強さとの関係 (Hesketh 1963)

この状態をわれわれは飽和したと呼んでいる，両者の関 係がこのような経過をたどるのは光が強くなると光より 次第に他の要素が光合成の制限因子となってくることを 意味していると言えよう，入射光に対しての利用効率を 計算したものを第 5 図に点線で示したが，光量が少くな る之利用効率は增加していき, 無限小の光量の時最大之 なる.すなわち立ち上りの接線の角度がその葉の最大利 用効率ということになる．乙れは非常に大きく，

$$
\begin{aligned}
& \text { トマト，キュウリ，テンサイ：15１9\% (Gaastra) } \\
& \text { アルファルファ, ベレニアルー: 19〜20\% (大久保ら) } \\
& \text { ライグラス } \\
& \text { 樹木 } \\
& \text { : 12〜14\%(Gabrielsen) }
\end{aligned}
$$

などの例がある.しかし前述のように光が強くなると効 率が低下し $4 \sim 5 \%$ なる．との利用効率低下の主因は $\mathrm{CO}_{2}$ と考えられ, 大気中の $\mathrm{CO}_{2}$ を高めると光合成量は 第 6 図に示すごとく，非常に多くなり，効率が高まり， 生育も促進され る. $\mathrm{CO}_{2}$ 濃度を大 気中より 5 倍の $1,500 \mathrm{ppm}$ に高め ると大豆の光合成 量は約 4.5 倍にな っている. このよ うに空気中の $\mathrm{CO}_{2}$ 濃度を高めて作物 を栽培する方法を 炭酸ガス施肥。 と呼んでいる. 最 近日本であ実用化 されだしたが，太 陽エネルギーの利 用効率を高めるこ

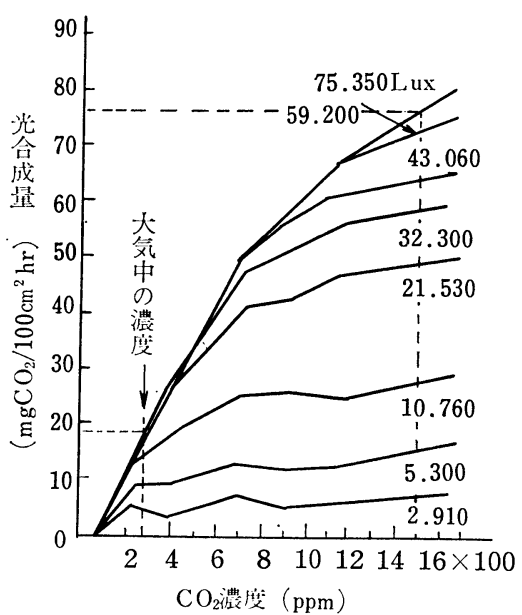

第 6 図大豆 (Hark) の $\mathrm{CO}_{2}$ 一光同化曲 線 (Brun, Cooper, 1967)

\section{とができる。}

なお生態的に非常に興味のあることは，光をよく受け る葉 (陽葉) と日蔭の葉 (陰葉) とでは第 7 図に示すご とく光一光合成曲線が異なり，陰量は立上りの効率が高 く，弱光の下で光合成がよくなるようになっており，陽 葉は光の強い時に効率がよく, 群落状態で上の葉と下葉 とでは光の受け方がちがっているが，植物は光を有効に 利用するようになっているのは自然の妙というほかはな ().

\section{f. 群落の光合成効率}

植物は自然状態では普通群落状態を呈している場合が ほとんどである．群落状態になると葉が光に対して重な り合ったり, 光が直ちに地表に落ちて有効に利用されな くなる．また前述のごとく光のスペクトル分布が異った
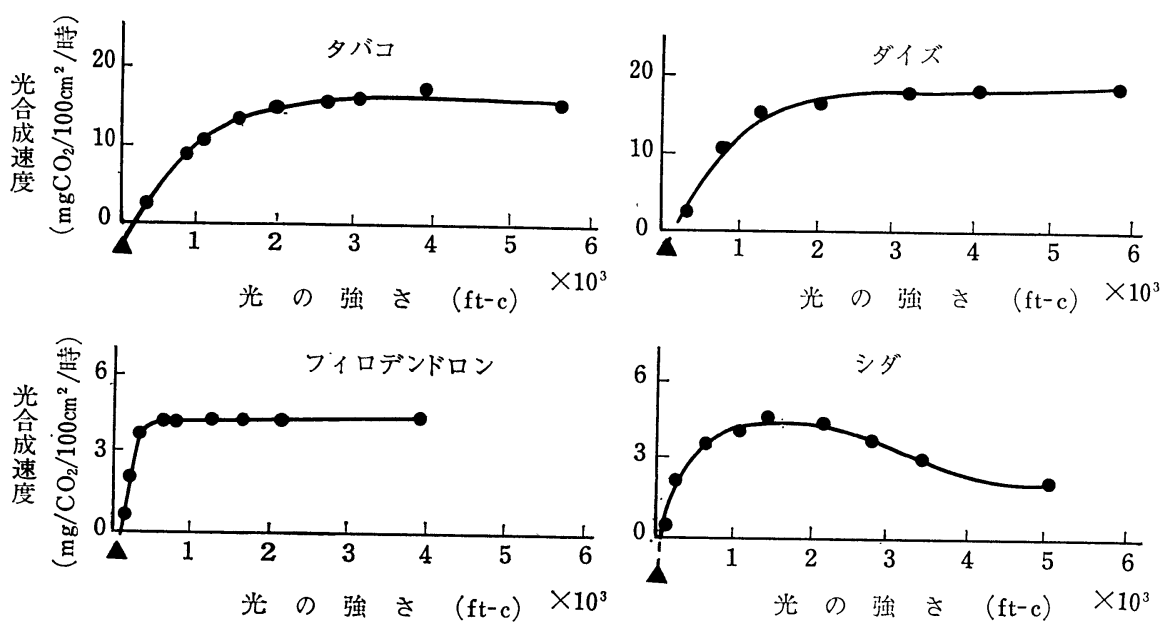

第 7 図 陽生植物之陰生植物の光一光合成曲線の例 (上: 陽生植物, 下: 陰生植物) 
り, 風速が異ったりで, 光合成む単葉とか個体の場合と 大変異ったものとなる. 数量が增すと単に量が增すとい うだけでなく，質的にす異ってくる．その他自然の環境 にさらされることああって, 現実の光合成量は単葉の場 合とは非常に異ったものとなっている．（第 7 図）全生 育期間についてエネルギーの利用效率をしらべて見ると 次に揭げるように非常に低いあのとなっている.

イネ: $1.6 \%$ ，ダイズ : $1.1 \%$,トウモロコシ $: 2.2 \%$,

テンサイ $: 1.8 \%$.

トウモロコシがあっとあ効率が高い。乙れは第 5 図にあ 示されている. 一般の植物は光があたると呼吸量が多く なるが (光呼吸)，トウモロコシは光呼吸をしないため

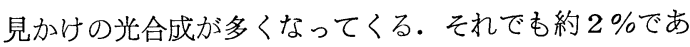
り，人間が食糧として利用する部分を考えるとさらに低 くなる. 長野農試で測定されたイネの固定エネルギーの 器官別蓄積量は次のごとくとなっている.

\begin{tabular}{clc}
\hline 全太陽放射量 & $553 \times 10^{3} \mathrm{Kcal} / \mathrm{m}^{2}$ & $100 \%$ \\
\hline 穂 & $3.72 \times 10^{3} \mathrm{Kcal} / \mathrm{m}^{2}$ & $0.7 \%$ \\
茎 & $2.13 \times 10^{3} \quad "$ & \\
葉 & $0.93 \times 10^{3} \quad "$ & \\
根 & $0.24 \times 10^{3} \quad "$ & \\
\hline 計 & $7.02 \times 10^{3} \quad "$ & $1.3 \%$ \\
\hline
\end{tabular}

穂に蓄積されるものが約 $0.7 \%$ ああるから，モミガラ やヌカを取去ると $0.5 \%$ 以下になるであろう.

極めて僅かな植物のエネルギー固定率の下で動物は生 命を維持しているととになる. 動物はさらにてのエネル ギーの10〜20\%を固定するに過ぎない.さらに動物を食 糧とする肉食の大動物は大変な量の太陽エネルギーを必 要とすることになり，植物プランクトン一動物プラン

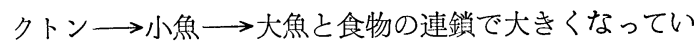
く大魚の太陽エネルギー利用効率は $10^{-3} \%$ 以下という ことになろう。鯀は胃袋に 1 トン以上の飼が入っている というから成角となるまでの太陽エネルギーの消費は大 変なむのであり, 大動物が生存していくととはエネルギ 一的に考え極めてむづかしい.

人類は食糧問題に直面し，世界の人口をどの位支えう るかという将来の地球管理計画が問題となっているが, 要はエネルギー伝達のどの段階のあのを食糧とするかと いうことにある．糓類を食べるか，肉食を主にするか， 牛乳にするか. 米が余ったから水田を牧草地に転換して 亩産を奖励するといっても肉にすれば，従来10人盖えた 水田で 1 人しか着えないととになる. 英国は経済的な問 題から食糧の輸入を制限し, 西部地方で牧場を麦畑に転 換しつつある. まったくとのエネルギー理論からの農政
である．単なる感覚の農政であってはならない。

なお最近都市緑化環境净化で都市林が問題となってい るが森林などの同化量 ( $\mathrm{CO}_{2}$ の吸収量) は $8 \sim 15$ ton/ha 程度であり，また人間が放出する $\mathrm{CO}_{2}$ 量を吸収してあ らうための緑地は大略 $30 \mathrm{~m}^{2}$ 程度と考えてよい.

\section{g. 日本および世界の光合成能分布}

光合成量を左右する要因は数限りなくあるが, 光は光 合成の 1 つのポテンシャルであるととから, 関原数打よ び Budyko の日本および世界の日射分布図と，Gaastra のテンサイの光一光合成曲線を用いて光合成能分布を求 めたものを第 8 図および第 9 図に揭げる. 鳥取一島根, 新潟一長野一山梨などの県がポテンシャルが高い. 大阪 などでは・米作日本一、などが出るととはまず不可能に 近い.

$\mathrm{mgC} \mathrm{O} / 100 \mathrm{~cm}^{2} / \mathrm{hr}$

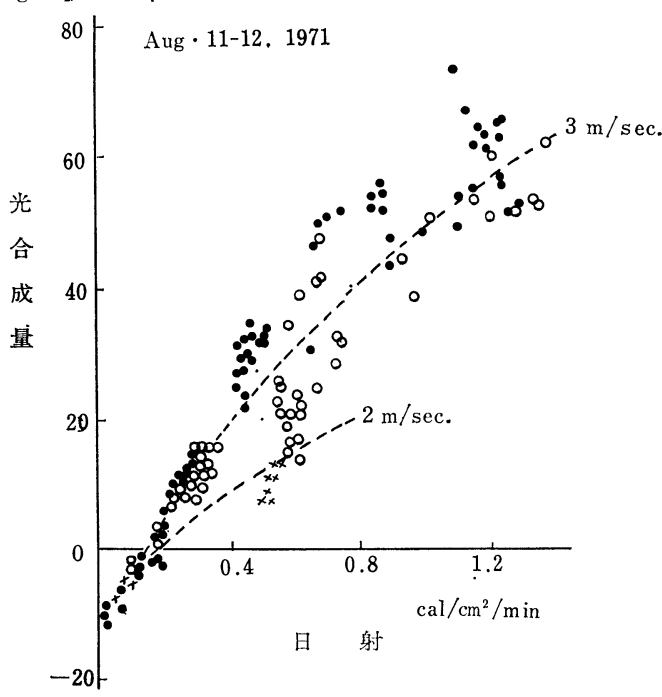

第 8 図水稻群落の光合成 （風速によって $\mathrm{CO}_{2}$ の輸送量が異るた め光合成量も異る。 $\times: 1.5 \sim 2 \mathrm{~m} / \mathrm{sec}$. $\circ: 2 \sim 3 \mathrm{~m} / \mathrm{sec} . \bullet: 3 \sim 4 \mathrm{~m} / \mathrm{sec}$.) （矢吹・青木 1972）

世界の分布を見ると将来の食糧問題はポテンシャルの 高い砂漠地带あるいは中国の開発にかかっているように 思われる.

\section{h. 大気污染と光合成能}

工業地带では工場から出る污染物により, 空気の組成 が異なり $\mathrm{SO}_{2}$ や $\mathrm{NOx}$ など植物が発生以来順応してき た空気の組成とは異ってきたため彼らの污性に異状をき たした. 第11図は堺市内のサンゴジュの光合成能の分布 であるが, 污染地带の污性の低い処は山間部の污性の高 い処の $1 / 2$ 以下の光合成量となっている. この分布は大 
気中の $\mathrm{SO}_{2}$ 分布だけでは律せられず複雑である. これ らの葉を分析して見ると $\mathrm{Zn}$ や Feなどが多い. 数年前 大阪市のサンゴジュの光合成能を測定したが，その時は $\mathrm{SO}_{2}$ と極めて類似した分布を示したが，乙の図から堺市 内では臨海工業地带より排出する污染物が複雑であるこ とがわかる. また都路沿いの植物には $\mathrm{Pb}$ を多く含んで いる. これは自動車の排気ガスによるすのと考えられ る.

\section{IV. 形態形成と太陽}

“花は春になり暖かくなって開くもの之思っていた が，英国に来て驚いたととは英国では寒くても春が来る と花が咲く，彼らは春を知っている、とロンドン駐在の 商社マンである友人が私に語ったととは大変印象的であ った．英国の早春の自然はいろいろな花で飾られるが, 友人の言葉には非常に重要な意味が含まれているように 思われる.
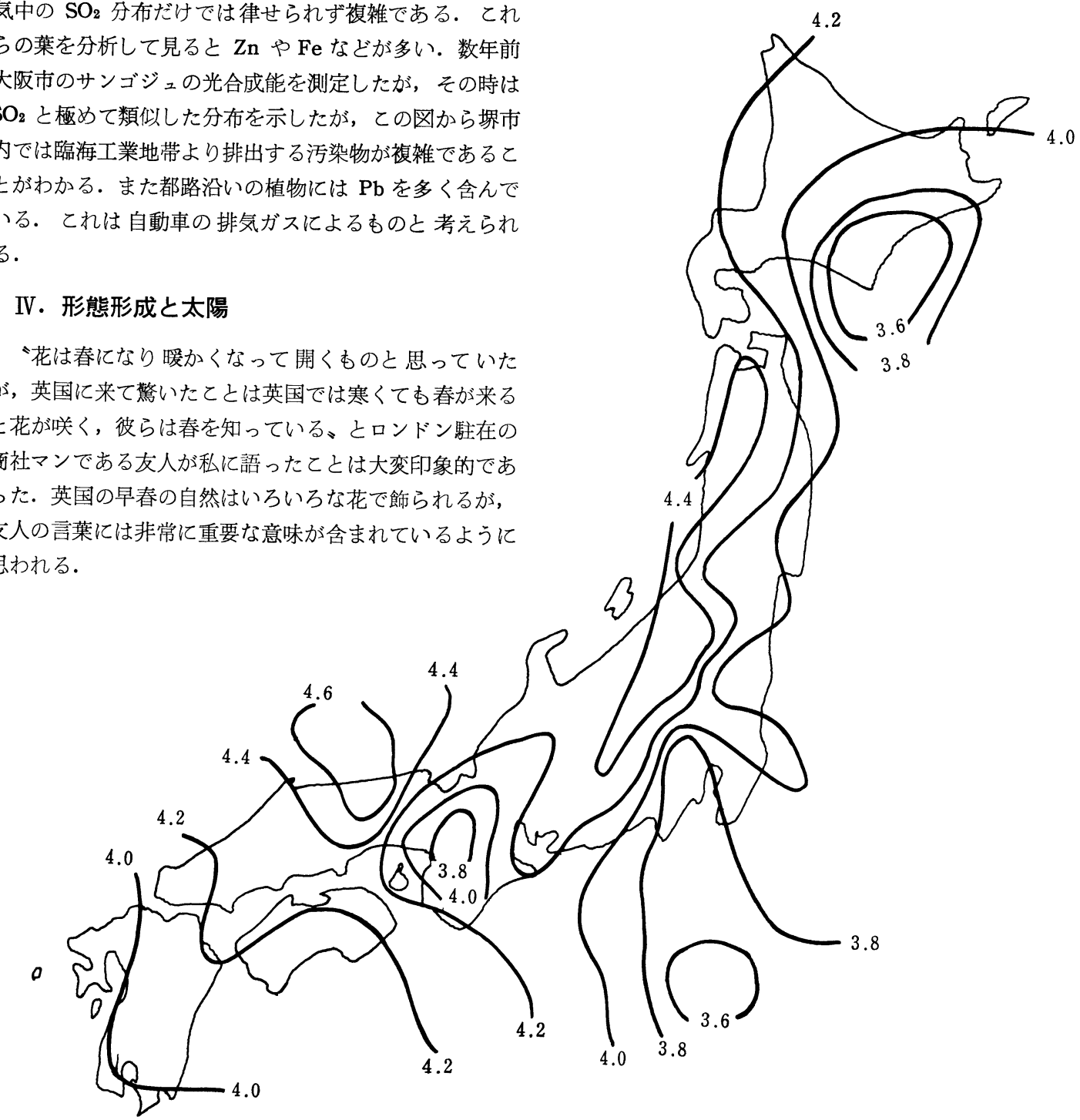

第 9 図 日本における日射量からみた夏期の光合成能分布（矢吹原図）

カーネーション・ペチュニアなどは日の長い初夏に花 が咲き, 菊やアサガオは特別な操作をしない限り, 日が 短かくなる秋にしか花をつけない，とのように植物はい つ花を開くかそれぞれ决っている. 種子が芽を出し, 茎 や葉が繁る時代を栄養生長期と呼び, 上述の光合成によ って生長をつづける. ある時期がくると花芽がつき開花 し実を結ぶ。この期間を生殖生長の時代と言っている. このような形態形成は外界のいろいろな条件が影響して いるが, とくに昼の長さと温度が関係し, 昼の長さが决 定的な原因とされている.

光合成反応は18世紀末期にはかなりの点まで明らかに され 200 年近い歴史があるが, 日長反応が初めて気付か
れたのは 1920 年でそれから今日までたかだか 50 年であ る、日が短かくなって開花するキクに夜光を与えて日を 長くし開花を阻止する電照ギクなどの応用研究が盛んに 行なわれてきたが，乙の反応のエネルギー受容体である フィトクロームが分離されたのが1959年であることから もわかるように，日長反応 (形態形成) の問題はほとん ごが末解決である.

フィトクロームは酵素として働らき， $\mathrm{P}_{\mathrm{R}}$ 型と $\mathrm{P}_{\mathrm{FR}}$ 型 の二種があって， $P_{R}$ 型は赤色光を， $P_{F R}$ は遠赤色光を 吸収する、 $\mathrm{P}_{\mathrm{R}}$ 型が増加すると花芽の分化が促進される が短日植物は夜の間 (暗期) に $\mathrm{P}_{\mathrm{FR}}$ 型から $\mathrm{P}_{\mathrm{R}}$ 型に転化 する.いま暗期の中途で赤色光 $(650 \mathrm{~nm})$ で照射すると 


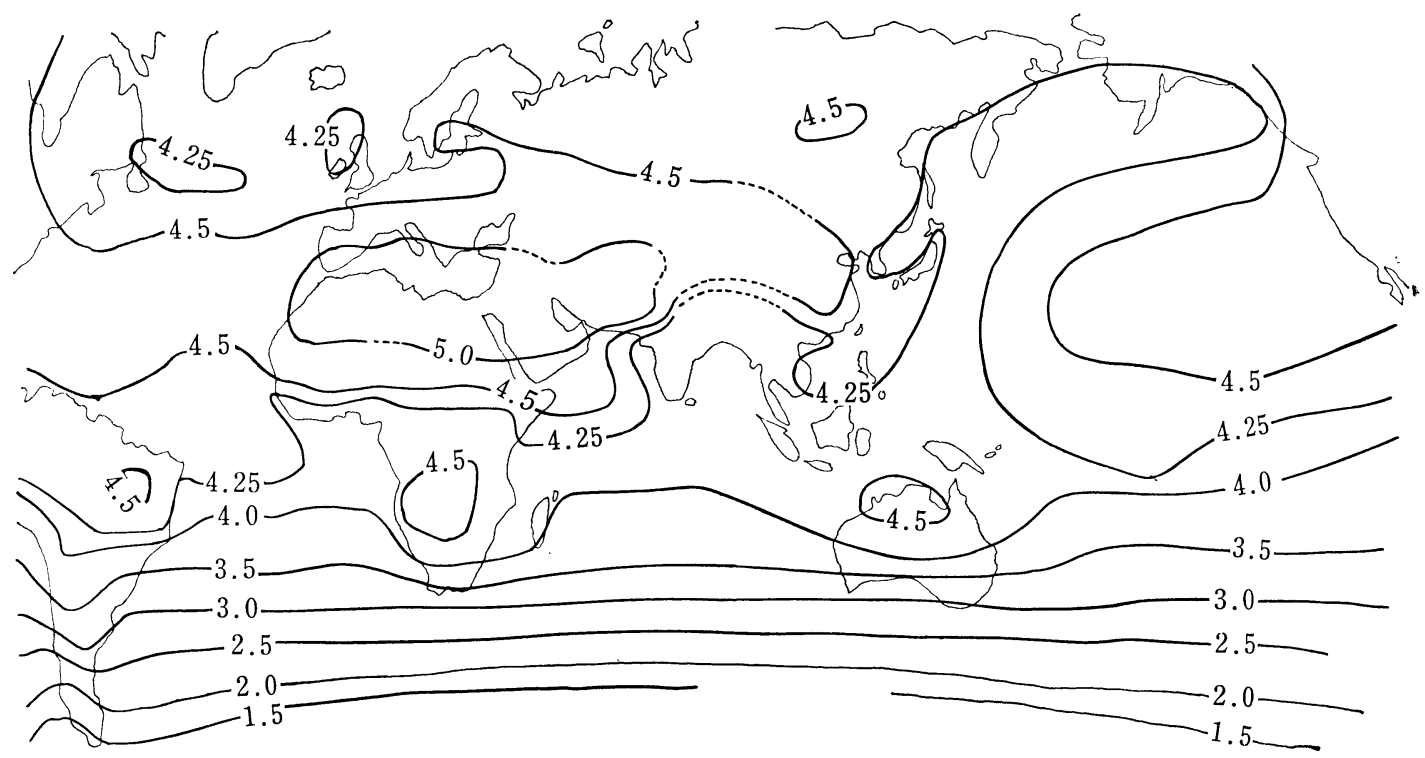

第10図 世界の日射からみた 7 月における同化能分布（矢吹原図）

$\mathrm{P}_{\mathrm{R}}$ 型からあとの $\mathrm{P}_{\mathrm{FR}}$ 型にもどり, 花芽の形成は阻止さ れる. その直後遠赤色光 $(730 \mathrm{~nm})$ を照射すると $\mathrm{P}_{\mathrm{R}}$ と なり赤色光の作用が打ち消される.との作用は反復的で 最後に赤色光を与えたか遠赤色光をあてたかということ によって花茅の形成が阻止されたり促進されたりする。 これと暗期中断と呼んでいるが，このととから花芽の形 成に関係するのは昼の長さでなく，実は夜の長さである ととがわかる。

暗期中断は農業にとっては非常に有効で，今迄短日植 物の花芽阻止のため電灯をつけて日を長くしていたが, 真夜中に短時間期中断を行うことによって目的が達せら れるようになり経済的となった。

このフィトクロームによって日長反応のすべてが解決 するかに見られたが，乙れでは説明できない事実が多く 見出され，内生リズム説む重視されている．乙れは植物 に一定の明喑のリズムを与えると植物は日周期のリズム の生理現象が現われるとするむので，滝本氏ら（1964） の実験によるとアサガオを連続照射の下においた後で暗 室に移し，いろいろな時間に赤色光を 5 分間照射し，乙 れを育て花芽の数を測定したところ，暗期開始から 8 時 間，32時間を中心に花の数が少なく，24時間のサイクル で花芽形成のリズムのあるととが認められた。

形態形成の作用スペクトルは第 1 図に与えたが. 反応 に対する光エネルギーを測定して見ると極めて低エネル ギーで反応が行なわれていることがわかった。長日植物 のアラセイトゥ（ストック）は 10 f.c. で開花が促進さ れ，エゾギク (アスター) は 0.3 f.c. でその効果は著し く, 0.1 f.c. であ茎の伸長と開花の促進に効果が認めら
れる. 0.1 f.c. の光の強さというのは満月の $2 \sim 3$ 倍ぐ らいの強さに過ぎない. かって千葉県の菊栽培農家を訪 れた時, 月の光であ効果が現われるようだと話してい た．それほどにての反応は低エネルギーでおこる。

黄色ダイズでは 1.4〜3.1 lux，オナモミは 0.6〜2.0 lux (0.056 f.c. 〜0.18 f.c.) という資料あある.

てのように低エネルギーで反応が起とるため, エネル ギーとしては余り問題にならない，その点農業上に利用 しようとする時はまことに便利であるが, 街灯, 高速度 道路の照明などの作物への影響は容易に起り易く，公害 の一因になっている. そてで Safly light が浮び上って くることになる。

\section{b. 日長の年変化}

地球の回転軸が軌道平面に対して $23.4^{\circ}$ の傾きを持っ て自転しながら公転していることから日長の年変化を生 じ，四季ができてくる，ての日長年変化は緯度によって 異なり，第12図のごとくである．乙の図は薄明，薄暮の 時間も入った植物学的なもので, 単なる日長時間ではな い. 大阪附近の日長は夏至で約 16 時間 15 分, 冬至で 7 時 間 45 分程度である。

日長の変化は上述のように植物の形態形成に大きい影 響を与えているが，緯度による变化す当然ながら植物の 自然分布に大きく影響している．植物の原産地をしらべ て見ると，低緯度に原産地を持つあのは短日植物で, 年 中花が咲き, 温帯から高緯度地方に自生する植物は長日 性で夏季に開花し, 中間の温带地方では両型が共存し, 長日型のあのは春から夏にかけて, 短日型のものは秋に 開花する，短日型のあのが高緯度に育った場合，秋にな 


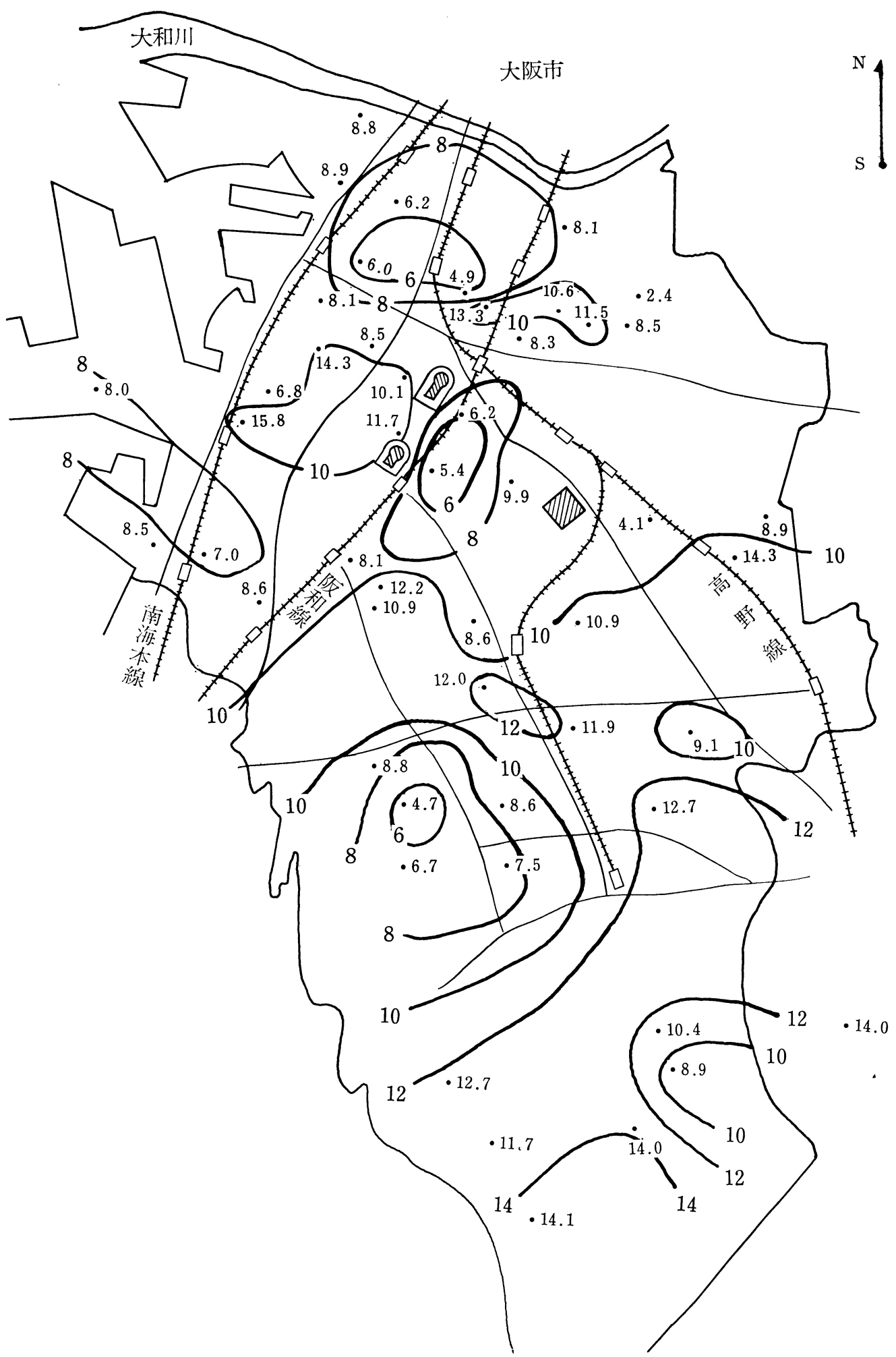

第11図 堺市内・サンゴジュの光合成能の分布（1972年12月） 单位 $\mathrm{mgCO}_{2} / 100 \mathrm{Cm}^{2} \mathrm{hr}$. (知吹原図) 


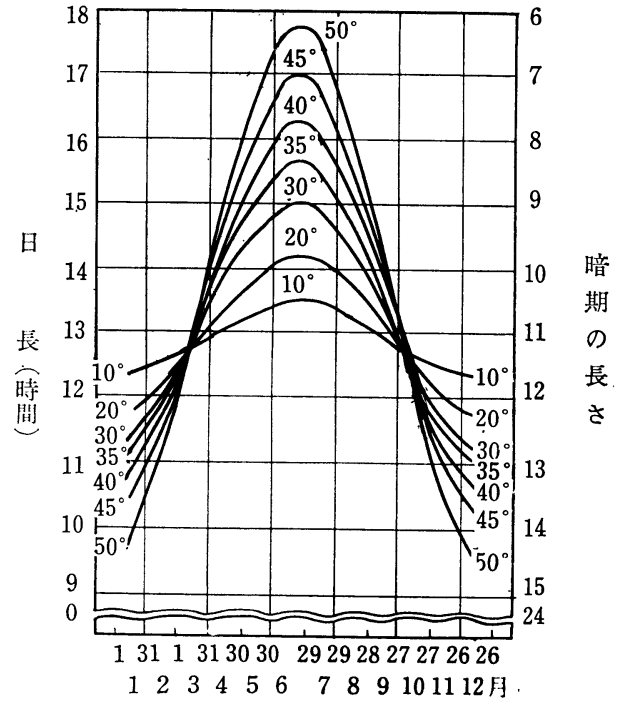

第12図 北緯 $10 \sim 50^{\circ}$ における明期（朝夕の薄 明, 薄暮を含む) の長さの季節的变化 (Borthwick ら (1956) による)

り日が短かくなった頃には寒さがきて枯死するが，開花 せず結局繁殖をしないととになる.乙のようなととから 自然に植物分布が決ってくる. 南北回帰線の間が原産で あるキビ, トウモロコシなどは短日植物であり, 緯度の 高い温帯地方に原産地をむつオオムギ，コムギ，ライム ギなどは長目型である．ダイコンを熱帯地方に移すと花 が咲かなくなり，サトウダイコンは二年生の植物である が，北極地方では一年生植物となる．また例えばアカバ ナの類のある植物は東半球に広く分布しているが，同一 種であってあ産地によって日長型が異なり， $61^{\circ} \mathrm{N} \sim 43^{\circ}$ $\mathrm{N}$ のあのは長日型, $43 \sim 36^{\circ} \mathrm{N}$ のむのは中性型, $34^{\circ} \mathrm{N}$ $26^{\circ} \mathrm{S}$ のものは短日となっている，つまりどの種でもそ れぞれ一定の緯度すなはち一定の光の下ではじめて適し た発育をすることになる. 緯度と植物は從来から温度条 件で説明されていたととも日長に起因することが多いで はなからうかと考えられ, 北欧の生態学者 H. Lundegarth は“環境順化試験の多くの失敗は温度関係で説明 できると信じられてきたが，あっとよく研究すれば光条 件の不適当のために起ったものであるととが判明するか あ知れない、と言っている.

日長に関連しさらに複雑さを増すのはすでに述べたで とく, 緯度によって太陽高度がちがうことから，地表に 到達する光のスペクトルが異ることである・高緯度にな る之赤色光の領域が他の領域に比べ相対的に多くなって くる.たびたび述べたごとく日長反応は赤色光および遠 赤色光が関係しているから，日長時間以外にてのスペク トルの問題が関係してくるはずである.しかしとの点に
ついての究明はほとんどなされておらず今後の興味ある 研究課題となっている.

農村が市街地化され，高速道路が建造されるととによ り，照明と農作物の問題が各地で起っているが，ての問 題解决は大变難しい. 前述のごとく植物の光感応度の低 い波長部分を用いた Safe light を用うるの屯一つの方 法であろう. また最近の形態形成反応の研究によると赤 色光と遠赤色光との照射比を变えることにより，照明を しても短日条件が維持されるという現象が見出されてい る.この現象がさらに精しく究明されれば, 道路照明に 応用するととも出来るであろう。

簡単に形態形成と太陽エネルギーについて触れたが, これに関する研究は膨大にあり，しかす今後の研究にま つととが極わめて多いという非常に難しくかつ興味深い 問題である.

\section{V.むすび}

度々強調したでとく, 太陽一植物一生物というエ ネルギーによって連らなり，てのバラスは長い地球上の 生物の歴史によって整然と保たれている。 その中の $1 つ$ が乱されても生物は生きつづけると之は困難となる。と てろがこのバランスを崩しているのが他ならない人間で あり，そのは板返りはすでに現われている．まずわれわ れは植物之ともに，生物之とあに共存して行くというこ とを考えて, 今後の食糧・エネルギー問題を考えていか ねばならないであろう。

植物がかって固定した太陽エネルギー一一石油もあと 30年で尽きるというローマクラブの報告むある，真夏に 地上に注がれる太陽エネルギーを $1 \mathrm{KW} / \mathrm{m}^{2}$ としても植物 が固定するのは $20 〜 30 \mathrm{~W} / \mathrm{m}^{2}$ に過ぎないが，乙の僅かな エネルギーも利用しなければならない時代が遠からず来 るのではないかと真剣に研究されるようになってきた。 また東南アシアの森林が伐採され用材として利用されて いる.乙れらは100年200年以上の太陽エネルギーの蓄積 によるものと一朝一夕に成るものでない，いかに科学技 術が進歩しようと人類生存の基調は生物生産にあること を考え食糧, エネルギー問題を考えなりればならない。

\section{参考文献}

田口亮平 : 作物生理学, 盖賢堂版

戸刚義次編：作物の光合成之物質生産, 養賢堂版

塚本洋太郎：花弁総論, 養賢堂版

大久保ほか：J. I. B. P. 門司班報先（1970）

矢吹・青木 : J. I. B. P. 門司班報先 (1972)

尾田義治: 昭和 41 年度生物環境調節研究会研究報告

ケーメン, M. D. : 光合成の物理化学, 福田音二郎訳, 共 立共版版.

ブディコ, M : 気候と生命, 内島, 岩切沢, 東大出版版.

Seigen, H. H. and W. D. EcElroy : Light : physical and Biological Action. Academic Press.

その他，多くの交献によったが省略させていただく. 